\title{
Influence of Chicken Manure Applications on the Yield and the Essential Oil content of Origanum onites $\mathrm{L}$.
}

\author{
Ayşe Betül AVCl* \\ Odemis Vocational School of Ege University, 35760, TURKEY
}

\begin{abstract}
Background: Origanum onites L. is one of the most important export plant collected from natural flora and cultuvated in Turkey. Methods: This study was conducted to determine the effects of different doses of chicken manure on yield characteristics of $O$. onites, in Odemis, Izmir ecological conditions during 2014 and 2015 vegetation periods. The experiment was established as randomized blocks design with three replications and five chicken manure $\left(0,10,20,30,40\right.$ ton ha $\left.^{-1}\right)$ were applied. Results: Plant height, fresh herb yield, dry herb yield, dry leaf yield, dry stem yield and essential oil content were significantly affected by year, harvest number and chicken manure doses. Mean value of the plant height ranged between 56.80 to $94.87 \mathrm{~cm}$, fresh herb yield was $54000.0-135150.0 \mathrm{~kg} \mathrm{ha}^{-1}$, dry herb yield was $5770.7-31040.7 \mathrm{~kg} \mathrm{ha}^{-1}$, dry leaf yield was $3560.7-15470.7 \mathrm{~kg} \mathrm{ha}^{-1}$ and dry stem yield was $1430.6-19060.0 \mathrm{~kg} \mathrm{ha}^{-1}$. The total essential oil content ranged between $3.5-5.4 \%$. Conclusion: For the highest drog herb and drog leaf yields, which is the most important features for the production of oregano, 20 ton ha-1 of chicken manure application can be recommended. 30 ton ha-1 chicken manure dose can be suggested as the effective for the essential content.
\end{abstract}

Key words: Oregano, Fertilization, Fresh herb yield, Dry herb yield, Dry leaf yield, Essential oil.

\section{INTRODUCTION}

Oregano (Origanum onites L.) belongs to the Lamiaceae family is a perennial plant and is widespread in the West and South part of Turkey. ${ }^{1}$ Turkey is one the biggest oregano producers in the world of exports 15161 tons of oregano from $\$ 3.7$ per kilogram in 2015. ${ }^{2}$ The most exported Origanum species of Turkey are Origanum onites, O. vulgare subsp. birtum, O. minutiflorum, O. dubium, O. syriacum var. bevanii. The other species used as oregano in our country are Thymbra spicata, T. sintenisii, Coridothymus capitatus, Satureja cuneifolia, S. hortensis, S. montana, S.spicigera.

Origanum genus is widely used as spices, $\mathrm{fla}$ vouring of food products as well as cosmetic and cleaning industry. Also; their essential oils are used as natural food preservatives because of antioxidant and antimicrobial activities. The essential oil content of Origanum onites is ranging from $1.8 \%$ to $4.5 \%{ }^{3}$. The main constituent of the Origanum essential oil is mostly carvacrol. A carvacrol content changing from $51.0 \%$ to $84.5 \%{ }^{3}$

Plant nutrition is one the most important factors that increase plant production and nitrogen is the most recognized in plants for its presence in the structure of the protein molecule. ${ }^{3}$ The mineral nutrition of herbs can affect oil production and quality. ${ }^{4}$ A successful fertilizing program adds enough nutrient elements to the soil to promote growth and/or oil production. ${ }^{5}$ In sustainable agriculture, organic fertilizers not only supply plant nutrients but also improve soil organic matter contents. ${ }^{6}$ Nitrogen fertilization reduced the essential oil content of some
DOI: 10.5530/ijper.51.3s.32

Correspondence:

Ayşe Betül AVCl,

Odemis Vocational School of Ege University, 35760, TURKEY

Contact: 902325452149 E-mail: avcibet@hotmail.com; ayse.betul.avci@ege.edu.tr

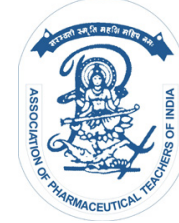

www.ijper.org 
plants such as juniper, thyme, anise and cumin. ${ }^{7}$ However; the essential oil concentration did not affect from the nitrogen application however, the herbage yield was affect. $^{8}$

In this study, it was aimed to determine the effect of the chicken manure on the plant height, fresh herb yield, dry herb yield, dry leaf yield, dry stem yield and essential oil content of Origanum onites grown in Odemis, Izmir ecological conditions.

\section{MATERIAL AND METHODS}

Origanum onites L. seeds were obtained from Field Crops Department of Agriculture Faculty, Ege University in Izmir, Turkey. The field research was conducted in the Odemis Vocational School of Ege University during the 2014 and 2015 growing seasons. The experiment was established as randomized blocks design with three replications. The parcels were planned in six rows of $3 \mathrm{~m}$ length with $250 \mathrm{~cm}$ between rows and the plant density was $40 \times 20 \mathrm{~cm}$. Seedling date was on 21 May, 2013. In parcels 4 middle rows with $2.5 \mathrm{~m}$ length were harvested. Plants were harvested at florescence stage. First year harvest was made in 2013 not taking into consideration. Harvests were done on April 24 ${ }^{\text {th }}$ and July $2^{\text {th }}, 2014$ and in the second year were on May $21^{\text {th }}$ and August $27^{\text {th }}$, 2015. Different chicken manure doses (control, 10, 20, 30, 40 tone $\mathrm{ha}^{-1}$ ) were applied for three years in 2013, 2014, and 2015. Soil samples taken from 0-20 cm and $20-40 \mathrm{~cm}$ depth of the experiment field were analyzed in the Soil Laboratory of Odemis Vocational School of Ege University. The soil was sandy loam $(69 \%$ sand, $24 \%$ loam, $7 \%$ clay) with $1.6 \%$ organic material and $\mathrm{pH}$ 7.3. At the end of the compositing process in chicken manure, the $\mathrm{pH}$ value was 6.02 , and organic matter and total $\mathrm{N}$ contents were $6.80 \%$ and $0.35 \%$, respectively. Available $\mathrm{P}\left(\mathrm{P}_{2} \mathrm{O}_{5}\right)$ was $22.5 \mathrm{mg} \mathrm{kg}^{-1}$ and the $\mathrm{EC}$ value was $0.04 \mathrm{~ms}$ in manure.

Plant heights were measured from soil level to the highest point with ten plants in each plot. Fresh herb yield was determined after the shelter side effects were left; the remaining plants in each plot were cut with saw knife $10 \mathrm{~cm}$ above the surface and immediately weighed for obtaining plot yield. Then plot yield was transformed to yield per hectare $\left(\mathrm{ha}^{-1}\right)$. Dry leaf yield was obtained from a sample of $500 \mathrm{~g}$ of the fresh herb taken from each plot; these samples were then dried in an oven at $30^{\circ} \mathrm{C}$ for $72 \mathrm{~h}$ and the samples were weighed. Then the leaves of the samples were separated from the stem by hand and weighed. The ratio of dry leaves to fresh herb was thus obtained and the dry leaves yield was calculated per hectare. The essential oils were extracted by hydro distil- lation for $3 \mathrm{~h}$ using a Clevenger type apparatus with $10 \mathrm{~g}$ of the oven-dried samples at $30^{\circ} \mathrm{C}$ for $72 \mathrm{~h}$ harvested from each plot in different harvest time in both years. The essential oils were stored in dark glass bottles at $4 \circ \mathrm{C}$ until analysis. ${ }^{9}$ The essential oil content was measured by the volumetric method $(\mathrm{v} / \mathrm{w}) \cdot{ }^{10}$ Every characteristic were subjected to analysis of variance in the TARIST statistics soft-ware package according to the experimental design of randomized blocks. Differences were determined by the $\mathrm{F}$ test and mean values were compared according to LSD test.

\section{RESULTS AND DISCUSSION}

The studied parameters were found statistically different under the different chicken manure fertilization doses. All the research factors and their interactions were found statistically significant for all the fresh herb yields. The application doses of chicken manure were examined in terms of the fresh herb yield and stem yield; 40 ton $\mathrm{ha}^{-1}$ application provided the highest value; by comparison 20 ton $\mathrm{ha}^{-1}$ application was the most highest for the herb and leaf yields. The highest value for the essential oil content was obtained from 30 ton ha ${ }^{-1}$ chicken manure doses.

Significant differences were observed between year, harvest time, and their interactions for the plant heights (Table 1). Plant heights varied between 56.80 and 94.87 $\mathrm{cm}$ in the first year and 69.87 and $91.17 \mathrm{~cm}$ in the second year. In interaction between the year and harvest time, the highest plant heights were $89.69 \mathrm{~cm}$ in first harvest for the first year and $85.00 \mathrm{~cm}$ in the second harvest for the second year. There was no similarity found among the years according to harvest times.

The interaction of the year, harvest time and chicken manure application doses were found statistically significant for fresh herb, dry herb, dry leaf and dry stem yields (Table 1, 2, 3). Fresh herb yields varied between 54000.0 and $135150.0 \mathrm{~kg} \mathrm{ha}^{-1}$ in the first year; 21850.0 and $65650.0 \mathrm{~kg} \mathrm{ha}^{-1}$ in the second year. When the general averages of fresh herb yields were investigated for the first year, the highest values were recorded from the 40 ton $\mathrm{ha}^{-1}$ application for the $1^{\text {th }}$ harvest and the control for $2^{\text {th }}$ harvest. For the second year, the highest values were obtained from the 40 ton $\mathrm{ha}^{-1}$ application for the $1^{\text {th }}$ harvest and the 20 ton $\mathrm{ha}^{-1}$ application for $2^{\text {th }}$ harvest. The similarity was found for the first harvests in terms of the manure applications for the years but it was not valid for the second harvests.

Dry herb yields varied between 13918.3 and 31047.1 $\mathrm{kg} \mathrm{ha}^{-1}$ in the first year; 5776.7 and $18010.9 \mathrm{~kg} \mathrm{ha}^{-1}$ in the second year. In the first year, 40 and 30 ton ha ${ }^{-1}$ 


\begin{tabular}{|c|c|c|c|c|c|c|c|c|}
\hline \multirow[b]{3}{*}{ CMD* } & \multicolumn{4}{|c|}{ PLANT HEIGHT (cm) } & \multicolumn{4}{|c|}{ FRESH HERB YIELD (kg ha-1) } \\
\hline & \multicolumn{2}{|c|}{ First Year } & \multicolumn{2}{|c|}{ Second Year } & \multicolumn{2}{|c|}{ First Year } & \multicolumn{2}{|c|}{ Second Year } \\
\hline & $1^{\text {th }}$ harvest & $2^{\text {th }}$ harvest & $1^{\text {th }}$ harvest & $2^{\text {th }}$ harvest & $1^{\text {th }}$ harvest & $2^{\text {th }}$ harvest & $1^{\text {th }}$ harvest & $2^{\text {th }}$ harvest \\
\hline 0 & $82.10^{* * *}$ & 59.97 & 70.33 & 77.27 & $64300.0 \mathrm{~d}$ & 71133.3 a & $28000.0 \mathrm{c}$ & $21850.0 \mathrm{c}$ \\
\hline 10 & 88.17 & 62.00 & 69.87 & 83.93 & $90400.0 \mathrm{c}$ & $66733.3 \mathrm{ab}$ & $45250.0 \mathrm{ab}$ & $48750.0 \mathrm{~b}$ \\
\hline 20 & 93.40 & 56.80 & 75.53 & 91.00 & $96850.0 \mathrm{c}$ & $59600.0 \mathrm{ab}$ & $53950.0 \mathrm{a}$ & $65650.0 \mathrm{a}$ \\
\hline 30 & 94.87 & 59.33 & 72.67 & 81.63 & $120666.7 \mathrm{~b}$ & $54000.0 \mathrm{~b}$ & $37950.0 \mathrm{bc}$ & $50650.0 \mathrm{~b}$ \\
\hline 40 & 89.90 & 59.27 & 75.67 & 91.17 & $135150.0 \mathrm{a}$ & $55833.3 \mathrm{~b}$ & $56100.0 \mathrm{a}$ & $56250.0 \mathrm{ab}$ \\
\hline Mean & 89.69 a & $59.47 \mathrm{~b}$ & $72.81 \mathrm{~b}$ & $85.00 \mathrm{a}$ & 101470.3 & 61460.0 & 44250.0 & 48630.0 \\
\hline \multicolumn{5}{|c|}{ LSD(yxh): 3.618} & \multicolumn{4}{|c|}{ LSD(yxhxd):13585.4 } \\
\hline
\end{tabular}

*: Chicken manure doses, **: y: year, h: harvest, $d$ : chicken manure doses; $* * *$ : The columns with different letters mean statistically different according to LSD(p $\leq$ 0.05) test.

\begin{tabular}{l}
\multicolumn{8}{|c|}{ Table 2: Mean values of dry herb yield $\left(\mathbf{k g ~ h a}{ }^{-1}\right)$ and drog leaf yield (kg ha $\left.{ }^{-1}\right)$ of Origanum onites L. in different, } \\
year, harvest times and chicken manure doses \\
\hline
\end{tabular}

$*$ : Chicken manure doses, **: $y$ : year, $\mathrm{h}$ : harvest, $\mathrm{d}$ : chicken manure doses; ***: The columns with different letters mean statistically different according to $\operatorname{LSD}(\mathrm{p} \leq 0.05)$ test.

\begin{tabular}{|c|c|c|c|c|c|c|c|}
\hline \multirow[b]{3}{*}{ CMD } & \multicolumn{4}{|c|}{ DROG STEM YIELD (kg ha-1) } & \multirow{2}{*}{\multicolumn{3}{|c|}{ ESSENTIAL OIL CONTENT (\%) }} \\
\hline & \multicolumn{2}{|c|}{ First Year } & \multicolumn{2}{|c|}{ Second Year } & & & \\
\hline & $1^{\text {th }}$ harvest & $2^{\text {th }}$ harvest & $1^{\text {th }}$ harvest & $2^{\text {th }}$ harvest & $1^{\text {th }}$ year & $2^{\text {th }}$ year & Mean \\
\hline $0^{*}$ & $7960.1 \mathrm{c}^{* * *}$ & 7629.7 a & $2737.7 \mathrm{~b}$ & $1436.3 \mathrm{c}$ & $3.78 \mathrm{~b}$ & $4.33 \mathrm{~b}$ & $4.06 \mathrm{c}$ \\
\hline 10 & $11830.4 \mathrm{~b}$ & 6333.8 a & $4746.3 \mathrm{ab}$ & 3709.9 bc & $3.85 b$ & $4.82 \mathrm{ab}$ & $4.33 \mathrm{bc}$ \\
\hline 20 & $13078.8 \mathrm{~b}$ & 6617.7 a & 5429.3 a & $6501.5 \mathrm{a}$ & $4.50 \mathrm{a}$ & $4.78 \mathrm{ab}$ & $4.64 \mathrm{ab}$ \\
\hline 30 & $18568.0 \mathrm{a}$ & 5429.9 a & $3854.1 \mathrm{ab}$ & $5048.0 \mathrm{ab}$ & $4.67 \mathrm{a}$ & $5.07 \mathrm{a}$ & $4.87 \mathrm{a}$ \\
\hline 40 & $19060.4 \mathrm{a}$ & 5760.1 a & $5724.5 \mathrm{a}$ & $5958.6 a b$ & $4.68 \mathrm{a}$ & $4.37 \mathrm{~b}$ & $4.53 \mathrm{ab}$ \\
\hline Mean & 14099.6 & 6354.3 & 4498.4 & 4530.9 & $4.30 \mathrm{~b}$ & $4.67 \mathrm{a}$ & 4.48 \\
\hline \multicolumn{2}{|c|}{ LSD(yxhxd):2397.5 } & & & & \multicolumn{3}{|c|}{ LSD(yxd): $0.532 ; \operatorname{LSD}(d): 0.376$} \\
\hline
\end{tabular}

*: Chicken manure doses, $* *$ : y: year, h: harvest, $\mathrm{d}$ : chicken manure doses; $* * *$ The columns with different letters mean statistically different according to $\operatorname{LSD}(p \leq 0.05)$ test. 
applications were found significantly different for the first harvest, respectively; but there were no differences were found among the manure doses in the second harvests. For the second year, 40 and 20 ton ha ${ }^{-1}$ applications were found significantly different for the first harvest, respectively; and the 20 ton $\mathrm{ha}^{-1}$ was found for the second harvest.

Dry leaf yields varied between 7864.3 and $15477.0 \mathrm{~kg}$ $\mathrm{ha}^{-1}$ in the first year; 3566.5 and $10373.4 \mathrm{~kg} \mathrm{ha}^{-1}$ in the second year. In the first year, 30 ton $\mathrm{ha}^{-1}$ applications were found significantly different for the first harvest, but there were no differences were found among the manure doses in the second harvests. For the second year, 20 ton $\mathrm{ha}^{-1}$ applications were found significantly different for the first and the second harvests.

Dry stem yields varied between 5429.9 and $19060.4 \mathrm{~kg}$ $\mathrm{ha}^{-1}$ in the first year; 1436.3 and $6501.5 \mathrm{~kg} \mathrm{ha}^{-1}$ in the second year. In the first year, 40 and 30 ton ha ${ }^{-1}$ applications were found significantly different for the first harvest, respectively; but there were no differences were found among the manure doses in the second harvests. In the second year, 40 and 20 ton ha ${ }^{-1}$ applications were found significantly different, respectively; and the 20 ton $\mathrm{ha}^{-1}$ was found for the second harvest.

Significant differences were observed between year, chicken manure doses, year X harvest time and year X chicken manure dose interactions for essential oil content. As can be seen in table 3, the essential oil content ranged between 3.78 and $4.68 \%$ in the first year and between 4.33 and $5.07 \%$ in the second year and the general average of essential oil content was investigated as $4.48 \%$. In the first year the highest contents were obtained from 40, 30 and 20 ton $\mathrm{ha}^{-1}$ applications, respectively and were found statistically different then control and 10 ton $\mathrm{ha}^{-1}$ applications. In the second year the highest content was investigated from the 30 ton ha ${ }^{-1}$ application with $5.07 \%$. When the general averages of the chicken manure doses were compared, the highest value was recorded from 30 ton ha ${ }^{-1}$ application with $4.87 \%$ as it was found to be statistically significant.

\section{CONCLUSION}

Some researchers revealed that the nitrogen fertilization promotes the herbage yields and essential oil contents ${ }^{4,5,7}$ and some others also emphasized that the essential oil concentration did not affect from the nitrogen application however, the herbage yield was affect ${ }^{8,11}$ and describe as follows nitrogen promotes the branching and secondary stems so the oil concentration is affected by cultivation period but not by nitrogen. ${ }^{11}$

As a result of the study it was seen that the different chicken manure doses applied to oregano plants were effective on the yields characteristics and essential oil contents. For the dry herb and dry leaf yields, which is the most important features for the production of oregano, 20 ton ha ${ }^{-1}$ of chicken manure application can be recommended. 30 ton ha-1 chicken manure dose can be suggested as the effective for the essential content.

\section{ACKNOWLEDGEMENT}

None

\section{CONFLICT OF INTEREST}

None

\section{REFERENCES}

1. Tanker N, Koyuncu M, Coskun M. Farmasotik Botanik, Ankara Universitesi Eczacılık Fakultesi Yayinlari. 2007;93

2. Baser, KHC, Turkiye'nin onemli aromatik bitkileri ve ucucu yagları, Invited paper, MESMAP 2017, Cyprus.Acıkgoz N. Tarimda Arastirma ve Deneme Metodlari, E.U Ziraat Fakultesi Yayinlari, Bornova-Izmir; 1993.

3. Ninou EG, Paschalidis KA, Mylonas IG, Vasilikiotis C, Mavromatis AG. The effect of genetic variation and nitrogen fertilization on productive characters of Greek oregano. Acta Agrıculturae Scandınavıca, Sectıon B - Soil \& Plant Science. 2017;67(4):372-9.

4. Baranauskıeneú $R$, Venskutonıs $P R$, Vısÿkelıs $P$, Dambrauskıeneú E. Influence of Nitrogen Fertilizers on the Yield and Composition of Thyme (Thymus vulgaris). Journal of Agricultural and Food Chemistry. 2003;26(51):7751-8.

5. Elsayed OA. Response of wild egyptian oregano to nitrogen fertilization in a sandy soil. Journal of Plant Nutrition. 1999:22(1):103-14.

6. Yaldız A, Arıcı YK, Yılmaz G. Phytochemical Analysis, Antioxidant and Antibacterial Activities of Four Lamiaceae Species Cultivated in Barnyard Manure. Journal of Agricultural Sciences. 2017(23):95-108.

7. Hendawy SF, Khalid KA. Effect of chemical and organic fertilizers on yield and essential oil of Chamomile flower heads. Medicinal and Aromatic Plant Science and Biology. 2011;5(1):43-8.

8. Karamanos AJ, Sotiropoulou DEK. Field studies of nitrogen application on Greek oregano (Origanum vulgare ssp. hirtum (Link) letswaart) essential oil during two cultivation seasons. Industrial Crops and Products. 2013;246-52.

9. British Pharmacopoeia: Vol II. H. M. Stationary Office Londan; PA109, 1980.

10. Wichtl M. Die Pharmakognostisch-Chemische Analyse Akad. Verlagsgesellschaft, Frankfurt, 1971;479 p.

11. Sotiropoulou DE, Karamanos AJ. Field studies of nitrogen application on growth and yield of Greek oregano (Origanum vulgare ssp. hirtum (Link) letswaart). Industrial Crops and Products. 2010;32(3):450-7. 


\section{PICTORIAL ABSTRACT}

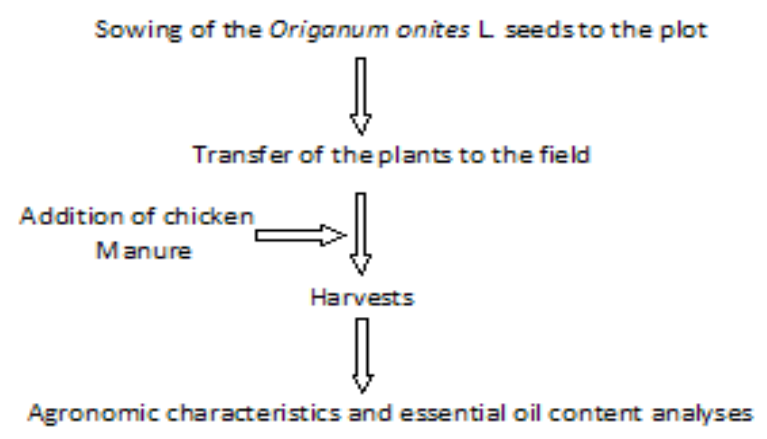

\section{SUMMARY}

- Origanum onites L. is a widespread in West and South part of Turkey and Turkey is one of the biggest oregano producers in the world and exports.

- This study was conducted to determine the effects of different doses of chicken manure on yield characteristics and essential oil content of Origanum onites L., in Odemis, Izmir ecological conditions during 2014 and 2015 vegetation periods.

- Plant height, fresh herb yield, dry herb yield, dry leaf yield, dry stem yield and essential oil content were examined as characteristics.

- Plant height, fresh herb yield, dry herb yield, dry leaf yield, dry stem yield and essential oil content were significantly affected by year, harvest number and chicken manure doses.

- Mean value of the plant height ranged between 56.80 to $94.87 \mathrm{~cm}$, fresh herb yield was 21850.0$135150.0 \mathrm{~kg}$ ha-1, dry herb yield was $5770.7-31040.7 \mathrm{~kg}$ ha-1, dry leaf yield was $3560.7-15470.7$ $\mathrm{kg}$ ha-1 and dry stem yield was $1430.6-19060.0 \mathrm{~kg}$ ha- 1.

- The total essential oil content ranged between $3.5-5.4 \%$.

- For the drog herb and drog leaf yields, which is the most important features for the production of oregano, 20 ton ha-1 of chicken manure application can be recommended.

- 30 ton ha-1 chicken manure dose can be suggested as the effective for the essential content.

\section{About Authors}

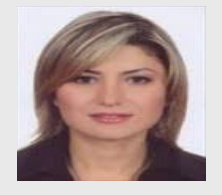

Dr. Ayse Betul Avci: Assoc. Prof. Dr. at Odemis Vocational School of Ege University, 35760 Izmir TURKEY. Interested in Cultivation of Medicinal and Aromatic Plants and Essential Oils.

Cite this article: $A \mathrm{VCl} \mathrm{AB}$. Influence of chicken manure applications on the yield and the essential oil content of Origanum onites L.. Indian J of Pharmaceutical Education and Research. 2017;51(3)Suppl:S290-94. 